\title{
IL18BP Gene
}

National Cancer Institute

\section{Source}

National Cancer Institute. IL18BP Gene. NCI Thesaurus. Code C118904.

This gene plays a role in interleukin sequestration. 